LIBRI

www.libridergi.org

Kitap Tanıtımı, Eleştiri ve Çeviri Dergisi

Journal of Book Notices, Reviews and Translations

Volume I (2015)

Nihal TÜNER ÖNEN, PLUTARKHOS, Agesilaos \& Pompeius. Antalya

2015. Akdeniz Uygarlıkları Araştırma Enstitüsü Yayınları, 539 sayfa.

Hellence Aslından Çeviren, Giriş, Değerlendirme ve Açıklayııı Notlar.

Ed. Murat ARSLAN. ISBN: 9786054483259

Özge ACAR

Libri: Kitap Tanıımı, Eleştiri ve Çeviri Dergisi'nde bulunan içeriklerin tümü kullanıcılara açık, serbestçe/ücretsiz 'açık erişimli' bir dergidir. Kullanıcılar, yayıncıdan ve yazar(lar)dan izin almaksızın, dergideki makaleleri tam metin olarak okuyabilir, indirebilir, dağıtabilir, makalelerin çıktısını alabilir ve kaynak göstererek makalelere bağlantı verebilir.

Libri, uluslararası hakemli elektronik (online) bir dergi olup değerlendirme süreci biten makaleler derginin web sitesinde (www.libridergi.org) yıl boyunca ilgili sayının içinde (Volume I: Ocak-Aralık 2015) yayımlanır. Aralık ayı sonunda ilgili yıla ait sayı tamamlanır.

Dergide yayımlanan eserlerin sorumluluğu yazarlarına aittir.

Künye N. TÜNER ÖNEN, Plutarkhos, Agesilaos \& Pompeius: Giriş, Değerlendirme ve Açıklayıcı Notlar. Antalya 2015. Akdeniz Uygarlıkları Araştırma Enstitüsü Yayınları, 539 sayfa. Ed. Murat ARSLAN. ISBN: 9786054483259 Tanıtan: Özge ACAR, Libri I (2015) 1-2. DOI: 10.20480/lbr.2018115452

Geliş Tarihi: 20.05.2015

Kabul Tarihi: 01.06.2015

Online Yayın Tarihi: 21.12.2015

URL: http://dx.doi.org/10.20480/lbr.2018115452

Editörya Phaselis Project

www.phaselis.org 


\author{
Nihal TÜNER ÖNEN, PLUTARKHOS, Agesilaos \& Pompeius. Antalya 2015. \\ Akdeniz Uygarlıkları Araştırma Enstitüsü Yayınları, 539 sayfa. \\ Hellence Aslından Çeviren, Giriş, Değerlendirme ve Açıklayıcı Notlar. Ed. Murat \\ ARSLAN. ISBN: 9786054483259
}

\title{
Özge ACAR*
}

Modern Batı Edebiyatı'nın önemli isimlerinden Montaigne'den Shakespeare'e pek çok yazarı etkilemiş, Hellen biyografi ve deneme yazarı Plutarkhos (MS 46-120) eserlerinin özgünlüğü ve kendine has üslubu ile Hellen yazımının kuşkusuz en önemli karakterlerinden biridir. Plutarkhos'un en popüler eseri, ünlü Hellen ve Romalı kişilerin hayatlarını kaleme aldığı Bioi Paralleloi/ Vitae Parallelae (Paralel Hayatlar) adlı biyografi dizisidir. Genel itibariyle bir Hellen ve bir Romalının yaşam öykülerinin ele alınıp senkritize edildiği bu dizide Plutarkhos, biyografi yazmadaki esas amacının tarih yazmak değil, ele aldığı kişilerin karakterlerini ortaya çıkarmak olduğunu bildirmektedir.

Akdeniz Üniversitesi, Akdeniz Uygarlıkları Araştırma Enstitüsü Yayınları tarafından Nisan 2015'te basılan, Yrd. Doç. Dr. Nihal TÜNER ÖNEN tarafından kaleme alınan Agesilaos \& Pompeius - Giriş, Değerlendirme ve Açıklayıcı Notlar adlı kitapta, Plutarkhos'un söz konusu biyografi dizisinden, Sparta kralı Agesilaos ile Romalı ünlü komutan Pompeius'un yaşam öyküleri ile karşılaştırma (synkrisis) bölümünün Hellence aslından Türkçe'ye çevirisi ve kapsamlı bir yorumlaması bulunmaktadır.

Önsöz, teknik noktalar, transkripsiyon ve kısaltma listelerinin ardından Giriş bölümünde ilk olarak Plutarkhos'un hayatı ve eserleri hakkında genel bilgi verildikten sonra Plutarkhos'un Paralel Hayatlar adlı eserindeki yazım amacı, kaleme aldığı çeşitli yaşam öykülerinden alıntılar yapılarak değerlendirilmekte, yazım yöntemi olarak ise, tüm bu yaşam öyküleri analiz edilerek, bir giriş bölümü (prooimion), biyografilerin anlatıldığı ikinci bir bölüm (historia) ve sonunda bir karşılaştırma bölümünden (synkrisis) oluşan bir şemanın izlendiği belirtilmektedir. Biyografilerin tarihlenmesi ve sıralanması aşamasında ise öncelik olarak Plutarkhos'un üç eserine ilişkin bizzat açıkladığı sıralama göz önünde tutulmakta, buna ek olarak biyografiler arasında uyguladığı çapraz referans yöntemi sayesinde çıkarımlarda bulunulmaktadır. Agesilaos \& Pompeius biyografileri özelinde ise, Caesar ve Brutus biyografileri ile yapılan gramatikal karşılaştırmalarla diyakronik bir tarihleme ve sıralama yöntemi izlenmektedir. Kitabın Giriş bölümünün sonunda ise, Plutarkhos'un biyografilerini yazarken kullandığı geniş yelpazedeki kaynaklar değerlendirilmekte ve bu aşamada, öncesinde bir eserin veya bir eserin bir bölümünün model olarak belirlendiği biyografilerin yazım aşamasına da değinilmektedir.

\footnotetext{
* M.A., Akdeniz Üniversitesi, Akdeniz Uygarlıkları Araştırma Enstitüsü, Akdeniz Eskiçağ Araştırmaları Anabilim Dalı, Antalya. ozgeacar90@gmail.com
} 
Giriş bölümünden sonra Agesilaos \& Pompeius çiftinin yaşam öykülerine geçilmektedir. İlk olarak bu yaşam öykülerine ilişkin yararlanılan edisyonlar hakkında bilgi verilmekte ve bu edisyonlar arasındaki noktalama ve yazım farklılıkları her iki çeviri öncesinde Çeviriye ilişskin Not başlı̆ı altında okuyucunun dikkatine sunulmaktadır. Biyografilerin Türkçe çevirileri ve Hellence asılları karşılıklı metinler halinde verildikten sonra her iki biyografinin ardından ayrıntılı Değerlendirme bölümlerine yer verilmektedir. Bu bölümlerde, her iki karakterin yaşam öyküsünün yapısı ve kompozisyon kurgusu başlıklar halinde özetlenip analiz edilmektedir. Bu aşamada, ağırlıklı olarak tematik yorumlama yöntemi izlendiği görülse de yazar ayrıca, Plutarkhos'un kendi anlatımını zenginleştirmek için kullandığı söz sanatlarını ele alarak filolojik yorumlamalara yer vermekte, Agesilaos dönemi Spartası ve Pompeius dönemi Romasına ilişkin diğer dönem tarihçilerinin anlatılarını da göz önünde bulundurarak karşılaştırmalar yapmakta ve söz konusu yaşam öyküsü anlatılarından kopmayı engelleyen bir naratolojik (anlatıbilimsel) yorumlama yöntemi ile okuyucuyu da ihmal etmemektedir. Kitabın başında genel olarak değinilen kaynaklar konusu, ele alınan her iki biyografinin değerlendirilmesi sonrasında daha detaylı bir şekilde incelenerek kitabın tematik biyografi anlatımı son bulmaktadır.

Karşılaştırma (Synkrisis) bölümünde ise, çeviriye ilişkin kısa notların ardından yine Hellence aslı ile birlikte Synkrisis bölümünün Türkçe çevirisi verilmekte, bu bölümün değerlendirmesi ise Plutarkhos Açısından Agesilaos ve Pompeius Çifti başlı̆ı altında sunulmaktadır. Bu bölümde ilk olarak Plutarkhos'un her iki biyografide kullandığı ahlaki nitelikler ele alınmakta, sonrasında ise söz konusu kişilerin siyasi ve askeri kariyerlerindeki başarı ve başarııılıklarından düşmanlara karşı tutumlarına, durum analiz yetilerinden ölümlerine kadar geniş bir yelpazede başlıklar altında incelemeler yapılmaktadır.

Agesilaos \& Pompeius biyografilerinin çevirisine ilişkin kişi, yer ve tarihsel olaylar hakkında okuyucuyu bilgilendirici notlardan oluşan Açıklayıcı Notlar bölümü, ardından gelen Bibliyografya ve Dizin bölümleri ile eser son bulmaktadır.

Son derece özenli bir çalışmanın ürünü olan bu eser, içerisinde bulunan titiz çeviriler, kapsamlı değerlendirme bölümleri, açıklayııı ve bilgilendirici notlar ile kuru bir antik kaynak çevirisinin ötesine geçmekte, Paralel Hayatlar biyografi dizisinin dilimize çevrilen diğer eserleri arasında bir başvuru kaynağı olarak kendine yer edinmektedir. 